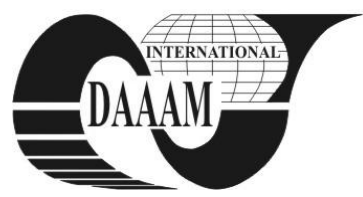

Annals of DAAAM for 2011 \& Proceedings of the 22nd International DAAAM Symposium, Volume 22, No. 1, ISSN 1726-9679 ISBN 978-3-901509-83-4, Editor B. Katalinic, Published by DAAAM International, Vienna, Austria, EU, 2011 Make Harmony between Technology and Nature, and Your Mind will Fly Free as a Bird Annals \& Proceedings of DAAAM International 2011

\title{
DIFFICULTIES ENCOUNTERED IN PERFORMING DISSIMILAR JOINTS ON SHEETS
}

\author{
MEDGYESI, T[iberiu]; POPESCU, M[ihaela] \& OPRIS, C[armen]
}

\begin{abstract}
When performing dissimilar joints on sheets many problems appear, having implications on their quality and the possibility to appear stresses and strains. After presenting shortly the problems specific to dissimilar joints and the possible joining techniques, with direct applicability on different base materials, the paper insists on the case study related to the CMT (Cold Metal Transfer) joining. Advantages when applying CMT are also evidenced, insisting on the technological side, but also on the environment protection. The experimental program consisting of destructive testing is also presented, together with the microscopic aspect of the joints obtained by the CMT process.
\end{abstract}

Key words: dissimilar joints, sheets, cold metal transfer (CMT), stress, strain

\section{INTRODUCTION}

Thin sheets can be joined by different joining processes, which must take into account their particularities. The joints to be obtained must be continuous, with good mechanical properties, without any stresses and strains. On the other hand, manufacturing of dissimilar joints from thin sheets raises supplementary problems. If spot welding or brazing were considered among the most commonly used, nowadays applicability tip the balance to processes such as TIG welding, laser beam welding respectively special variants such as MIG/MAG Tandem (developed by Cloos), CMT (developed by Fronius), Pulse-mix (a combination of CMT process and pulsed arc welding process, laser-CMT), TOPTIG and more.

Outstanding issues raised in these situations required specialized software applications, including finite element methods, with spectacular results and approaches in terms of economic efficiency.

\section{MAKING OF DISSIMILAR JOINTS}

Numerous applications of heterogeneous joints (copperaluminium, aluminium -steel, aluminium-magnesium) required by the automotive industry, the field of agriculture mechanization, imposed the development of studies with direct applicability results, as follows:

- galvanized steel-galvanized steel joints;

- steel-aluminium alloys joints;

- galvanized steel-aluminium alloys joints;

- aluminium alloys-magnesium alloys joints;

- nickel alloys-steel.

\section{CMT CASE STUDIES}

\subsection{General aspects}

The CMT joining variant uses especially the technology of assisted detachment of the droplet, the result can be called "joining drop by drop". Table 1 presents some of the technical characteristics of the Trans Puls Synergic 2700 CMT (Fronius) equipment. The weld-brazing CMR process is based on a completely new technologic principle, associated with specific equipment.

The inferior limit of applying the CMT joining process, with low heat input, is lower compared to conventional solutions with short arc and short-circuits transfer, which ensures a significant extension of the joining domain. Thermal power, respective the linear energy at CMT is lower compared to previously mentioned processes, with implications for joining similar or dissimilar thin sheets. In the case of conventional processes, using short arc or short-circuit transfer, the electrode wire has an advance motion until the short circuit is produced. The process is accompanied by abundant and uncontrollable spattering. In case of CMT joining, those situations can be avoided, since the wire performs an advance and retreat movement towards the part to be joined, with high frequency. High frequency oscillations of the wire contribute directly to the control of the process. Oscillation frequency of the wire varies in time, depending on the formation of short circuits, but the average is around $70 \mathrm{~Hz}$. The CMT process is extremely flexible, uses the process controller to monitor the working parameters and provides information on the principal technological steps.

\begin{tabular}{|l|c|}
\hline \multicolumn{1}{|c|}{ Technical characteristics } & TPS $2700 \mathrm{CMT}$ \\
\hline Power supply & $\begin{array}{c}3 \times 400 \mathrm{~V}, \\
+/-15 \%\end{array}$ \\
\hline Power consumption at $100 \%$ & $4,5 \mathrm{kVA}$ \\
\hline Current domain (MIG/MAG) & $3-270 \mathrm{~A}$ \\
\hline Current domain (electrode) & 10 - 270A \\
\hline Maximum current at $40 \%\left(10 \mathrm{~min} . / 40^{\circ} \mathrm{C}\right)$ & $270 \mathrm{~A}$ \\
\hline Maximum current at $60 \%\left(10 \mathrm{~min} . / 40^{\circ} \mathrm{C}\right)$ & $210 \mathrm{~A}$ \\
\hline Maximum current at $100 \%\left(10 \mathrm{~min} . / 40^{\circ} \mathrm{C}\right)$ & $170 \mathrm{~A}$ \\
\hline Working voltage $(\mathrm{MIG} / \mathrm{MAG})$ & $14,2-27,5 \mathrm{~V}$ \\
\hline Protection class & $\mathrm{IP} 23$ \\
\hline Insulation class & $\mathrm{F}$ \\
\hline Size $(\mathrm{mm})$ & $625 \times 290 \mathrm{x} 480$ \\
\hline Weight & $28 \mathrm{~kg}$ \\
\hline
\end{tabular}

Tab. 1. Technical characteristics of the Trans Puls Synergic 2700 CMT equipment

3.2 CMT dissimilar joining of galvanized sheets aluminium alloy sheets (GS-AS)

The experiments have been directed towards making dissimilar joints, galvanized sheets - aluminium alloy sheets (GS-AS), using the equipment presented in table 1 and the parameters presented in table 2 .

With the purpose of obtaining optimal joining parameters, it was imperative to establish the exact chemical composition of the base materials. That was conducted on an emission spectrometer. After grinding and polishing, the samples were etched as follows: for aluminium alloys the etchant was $\mathrm{H}_{2} \mathrm{O}$ and $\mathrm{HF}$, and for the steel the etchant was Nital 2\% (98\% ethanol and $\mathrm{HNO}_{3}$ ). 


\begin{tabular}{|c|c|c|c|c|c|c|c|}
\hline Sample & $\begin{array}{l}\text { Is } \\
{[\mathrm{A}]}\end{array}$ & $\begin{array}{c}\mathrm{Ua} \\
{[\mathrm{V}]}\end{array}$ & $\mathrm{s}[\mathrm{mm}]$ & $\begin{array}{c}\mathrm{ds} \\
{[\mathrm{mm}]}\end{array}$ & Wire & $\begin{array}{c}\text { Shielding } \\
\text { gas }\end{array}$ & $\begin{array}{l}\text { Gas } \\
\text { flow, } \\
1 / \mathrm{min}\end{array}$ \\
\hline 1 & 40 & 10.7 & $\begin{array}{l}1.5 \mathrm{AS}, \\
1.25 \mathrm{GS}\end{array}$ & 1.2 & \multirow{5}{*}{ AlMg3 } & \multirow{5}{*}{ Ar $100 \%$} & 10 \\
\hline 2 & 56 & 11.5 & $\begin{array}{c}1.5 \mathrm{AS}, \\
1 \mathrm{GS}\end{array}$ & 1.2 & & & 11 \\
\hline 3 & 50 & 11.4 & $\begin{array}{l}1.5 \mathrm{AS}, \\
1.25 \mathrm{GS}\end{array}$ & 1.2 & & & 10 \\
\hline 4 & 51 & 11.4 & $\begin{array}{l}1.5 \mathrm{AS}, \\
1.25 \mathrm{GS}\end{array}$ & 1.2 & & & 10 \\
\hline 5 & 62 & 11.8 & $\begin{array}{c}3 \mathrm{AS}, \\
1.25 \mathrm{GS}\end{array}$ & 1.2 & & & 12 \\
\hline
\end{tabular}

Tab. 2. Joining parameters for the CMT process

After sample preparation, the joints were ready for macroscopic and microscopic analysis. The macroscopic image of these joints reveal the formation of heat affected zones in the base materials, extended in the case of CMT joint samples number 1 and 4, compared to the other samples. At microscopic level, one can see that the zinc layer from the surface of galvanized sheet degrades in the heat affected zone, without any obvious modification of the structure. Remarkable is the fact that none of the samples (figure 1) show any alteration of the structure due to heating during the CMT process.

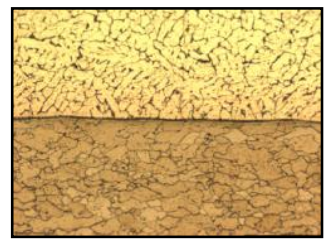

Fig. 1. Microstructure of the joint, OM 200x

$\mathrm{Al}-\mathrm{Mg}$ wire was use as filler metal, since one of the components is an AlMg3 alloy, containing 3-6\% Mg, with good corrosion resistance and high mechanical properties.

The Al-Mg system presents a eutectic reaction at $35 \% \mathrm{Mg}$ and $450^{\circ} \mathrm{C}$, leading to the formation of a eutectic mechanical mixture, composed of an $\alpha$ solid solution of magnesium dissolved in aluminium, and the intermetallic compound $\mathrm{Al}_{3} \mathrm{Mg}_{2}$. As a consequence, at room temperature, for the alloys that have up to $17,4 \% \mathrm{Mg}, \mathrm{Al}_{3} \mathrm{Mg}_{2}$ will precipitate as an intermetallic and secondary phase at the limit of $\alpha$ grains. Microscopic analysis of the joint emphasizes a structure composed of the $\alpha$ phase dendrites, and coarse $\mathrm{Al}_{3} \mathrm{Mg}_{2}$ particles, disposed at grain limits (figure 2,3). Notable is that precipitation of the $\mathrm{Al}_{3} \mathrm{Mg}_{2}$ phase at grain limits, increases the brittleness of the Al-Mg alloy.

Results of mechanical test conducted on the samples are presented in table 3. They show that the CMT joints have an adequate quality.

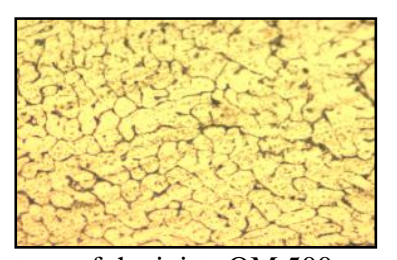

Fig. 2. Microstructure of the joint, OM 500x

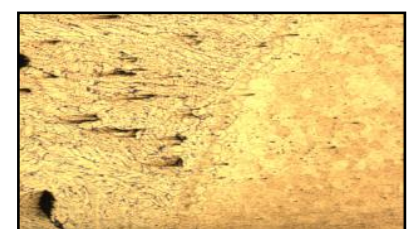

sample 1

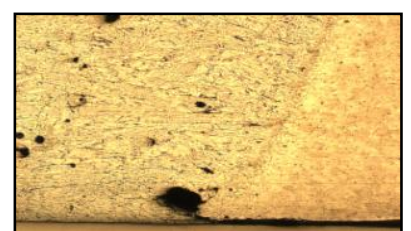

sample 3

Fig. 3. Microstructure of the joint, OM 500x

\begin{tabular}{|c|c|c|c|c|c|c|}
\hline \multirow{2}{*}{$\begin{array}{c}\text { Sample } \\
\text { no. }\end{array}$} & \multicolumn{2}{|c|}{ Joints size } & \multirow{2}{*}{$\begin{array}{l}\mathrm{F}_{\max } \\
{[\mathrm{KN}]}\end{array}$} & \multirow[b]{2}{*}{$\begin{array}{c}\mathrm{F}_{\mathrm{max}, \mathrm{med}} \\
{[\mathrm{KN}]}\end{array}$} & \multirow{2}{*}{$\begin{array}{c}\mathrm{R}_{\mathrm{m}} \\
{[\mathrm{Mpa}]}\end{array}$} & \multirow[b]{2}{*}{$\begin{array}{l}\mathrm{R}_{\mathrm{m}, \text { med }} \\
\text { [Mpa] }\end{array}$} \\
\hline & $\begin{array}{c}1 \\
{[\mathrm{~mm}]}\end{array}$ & $\begin{array}{c}\mathrm{H} \\
{[\mathrm{mm}]}\end{array}$ & & & & \\
\hline 1 & 20 & 2 & 3,08 & \multirow{5}{*}{3,16} & 77 & \multirow{5}{*}{91,90} \\
\hline 2 & 20 & 2 & 4,24 & & 106 & \\
\hline 3 & 20 & 2 & 2,79 & & 69,75 & \\
\hline 4 & 20 & 2 & 3,28 & & 82 & \\
\hline 5 & 20 & 2 & 4,99 & & 124,75 & \\
\hline
\end{tabular}

Tab. 3. Mechanical properties of the samples

\section{CONCLUSION}

Thin sheets raise problems when joining, requiring special precautions to avoid the apparition of internal tensions and deformations, and ensure continuity and quality of the joint. Thin sheets dissimilar joints raise supplementary problems, due to the heterogeneity of the base materials.

CMT is a joining process, recommended when joining thin sheets. Unwanted aspects (deformations, excessive penetration) at welding of thin sheets are avoided, since CMT is a process situated at the border between welding and brazing. Supplementary alloying of the filler metal with $1 \ldots 1.5 \% \mathrm{Si}$ leads to the apparition of a ternary eutectic, improving the fluidity and wetability. Microscopic analysis of the joint emphasized a structure composed of the $\alpha$ phase dendrites, and coarse $\mathrm{Al}_{3} \mathrm{Mg}_{2}$ particles, disposed at grain limits. Precipitation of the $\mathrm{Al}_{3} \mathrm{Mg}_{2}$ phase at grain limits, increases the brittleness of the $\mathrm{Al}-\mathrm{Mg}$ alloy.

CMT process eliminates one technological step, the removal of the zinc layer is not necessary prior to joining, as the classic welding processes require. New possible applications (components from agriculture equipments, air condition case) of the CMT are identified. Future research will concentrate on finding other thin base materials that can be joined with the CMT process.

\section{REFERENCES}

Popescu, M.; Magda, A.V.; Mocuta, G.E.; Damian, C. \& Perianu, A. (2008). Innovative welding processes thin sheet galvanized steel for automotive, 8-th International Conference Research and Development in Mechanical Industry, Radmi, Uzice, Serbia, 14-17 sept, ISSN: 8683803-21X, Dasic, P.V. (Ed.), pp. 280-284

Popescu, M.; Mocuta, G.E.; Magda, A.V.; Vartolomei, M. \& Groza, C. (2009). Economical Technology for Joining dissimilar materials in automotive industry, Annals of DAAAM \& Proceedings of the 20-th International DAAAM Symposium, 25-28 nov, Vol. 20, No.1, ISSN: 1726-9679, Katalinic, B. (Ed.), pp. 1143-1144

Popescu, M. \& Opris, C. (2010). Base elements for designing galvanized steel structures, Proceedings of the International Conference "Machine Design", Serbia, 18-19 mai, pp. 363366, ISSN: 1821-1259

Popescu, M.; Mocuta, G.E. \& Padurean, I. (2010). Galvanized plates behaviour during the exploitation temperature variations, Metalurgia, No.2, pp. 21-23, ISSN: 0461-9579

***Quintino, L.; Pimenta, G.; Iordanescu, D.; Miranda, R.M. \& Pepe, N.V. (2006). MIG Brazing of galvanized thin sheet joints for automotive industry, Material and Manufacturing Processes, Vol. 21, issue 1, pp. 63-73, ISSN: 0361-8773

***Zhang, H.T.; Feng, P.H., Zhang, B.B.; Chen, J.M. \& Wang, L. (2009). The arc characteristics and metal transfer behaviour of cold metal transfer and its use in joining aluminium to zinc-coated steel, Materials Science and Engineering, Vol. 499, Issues 1-2, pp. 111-113, ISSN: 0921-5093 